\title{
Comparison of Methods for Isolation of Bacterial and Fungal DNA from Human Blood
}

\author{
Tomasz Gosiewski • Leszek Szała • Agata Pietrzyk • \\ Monika Brzychczy-Włoch • Piotr B. Heczko • \\ Małgorzata Bulanda
}

Received: 7 March 2013/Accepted: 9 August 2013/Published online: 12 September 2013

(C) The Author(s) 2013. This article is published with open access at Springerlink.com

\begin{abstract}
The study aimed at optimization of DNA isolation from blood of representatives of four microbial groups causing sepsis, i.e., Gram negative: Escherichia coli, Gram positive: Staphylococcus aureus, yeast: Candida albicans, and filamentous fungus: Aspergillus fumigatus. Additionally, the five commercial kits for microbial DNA isolation from the blood were tested. The developed procedure of DNA isolation consisted of three consecutive steps, i.e., mechanical disruption, chemical lysis, and thermal lysis. Afterward, DNA was isolated from the previously prepared samples (erythrocyte lysis) with the use of five commercial kits for DNA isolation. They were compared paying heed to detection limit, concentration, DNA purity, and heme concentration in samples. The isolation of DNA without preliminary erythrocyte lysis resulted in far higher heme concentration than when lysis was applied. In the variant with erythrocyte lysis, two of the commercial kits were most effective in purifying the DNA extract from heme. Designed procedure allowed obtaining microbial DNA from all four groups of pathogens under study in the amount sufficient to conduct the rtPCR reaction, which aimed at detecting them in the blood.
\end{abstract}

T. Gosiewski $(\bowtie) \cdot$ A. Pietrzyk · M. Brzychczy-Włoch

P. B. Heczko · M. Bulanda

Chair of Microbiology, Jagiellonian University Medical College,

18 Czysta Str., 31-121 Kraków, Poland

e-mail: tomasz.gosiewski@uj.edu.pl

L. Szała

Institute of Mathematics, Silesian University, 74601 Opava,

Czech Republic

\section{Introduction}

Effective diagnostic of factors causing the infection is the most important, and most difficult, problem in the treatment of blood infections. It is decisive as regards the effectiveness of therapy and, consequently, the costs and the duration of hospitalization. The identification of etiological factors allows to employ efficient targeted antibiotherapy. The material submitted for the study is blood taken from patients manifesting clinical symptoms of sepsis. Until now, the so-called diagnostic "gold standard" has been constituted by blood cultures carried out on special growth media, preferably in automated cell culture systems. The advantages of such methods are their simplicity and relatively low costs of testing. Their weakness is that they are time-consuming, taking up to 5 days (until the test results are issued), and have low detection limit, which causes only 15-20\% of the culture to obtain microbial growth [3].

In order to enhance the chances of identifying microbes in blood, attempts are undertaken to identify them with the help of nucleic acid detection. The difficulty lies in isolating a proper quality of DNA matrix. It is necessary for it to be of the highest possible concentration. Fungi and different species of bacteria, which may be factors inducing sepsis (sometimes polietiological), are characterized by varied susceptibility to cell lysis and, consequently, the possibility of obtaining DNA from them may also vary.

In scientific literature, there is a lack of a description of a method for isolating DNA from blood which would be effective in the case of both bacteria and fungi. Many authors present methods which boil down to either isolating eukaryotic DNA from leukocytes or separately-from bacteria or from fungi $[1,2,8]$. There have been ready-touse kits available on the market for several years now, 
e.g., Septifast (Roche) or Septitest (Molzym), serving the purpose of detecting microbes in blood; however, the need for working on new solutions is still in order [5, 10].

The objective of the study was to develop a comprehensive method for microbial (bacterial and fungal) DNA isolation from blood to detect these pathogens and to evaluate the usefulness of commercial kits for DNA isolation.

\section{Materials and Methods}

\section{Microbial Strains}

Four strains were used in the research, these were representing groups diversified as regards the cell wall structure: Gram-negative Escherichia coli ATCC 25922 (American Type Culture Collection), Gram-positive Staphylococcus aureus ATCC 33497, Candida albicans ATCC 10231 yeast, and Aspergillus fumigatus ATCC 14110 filamentous fungus.

\section{Blood Samples}

Blood was collected from volunteers, who had no clinical symptoms of sepsis and no inflammatory markers (CRP and $\mathrm{OB}$ ). Blood samples were drawn into 2-mL Vacutainer $\mathrm{K}_{3} \mathrm{E}$ (Becton-Dickinson) test tubes. The research was granted approval by the local Bioethics Committee of the Jagiellonian University (KBET/94/B/2009).

\section{The Method for Microbial DNA Isolation from Blood}

DNA was isolated from $1.5-\mathrm{mL}$ blood samples, which were simultaneously inoculated with four model microbial strains (E. coli, S. aureus, C. albicans, and A. fumigatus), in order to obtain the cell number of $10^{6} \mathrm{CFU} / \mathrm{mL}$ for each of them. The number of the A. fumigatus conidia was determined by counting in a Bürker chamber.

The standardization of the method consisted in testing different variants of preliminary blood samples processing: (a) the samples were subjected to erythrocyte lysis in $0.17 \mathrm{M}$ ammonium chloride solution (Sigma) (at the same time, DNA was isolated to the exclusion of this stage, in order to compare results); (b) mechanical disruption was employed in the presence of glass beads $\phi 710-1,180 \mu \mathrm{m}$ (Sigma) in a FastPrep machine (MP Biomedicals); (c) enzymatic lysis of bacteria was conducted in the presence of the following enzymes: lysozyme $(2 \mathrm{mg} / \mathrm{mL})$, lysostaphin $(0.2 \mathrm{mg} / \mathrm{mL})$, and lyticase $40 \mathrm{U}$ (Sigma) at the temperature of $37^{\circ} \mathrm{C}$; and (d) the samples were subjected to $50 \mathrm{mM} \mathrm{NaOH}(\mathrm{POCh})$ at $95{ }^{\circ} \mathrm{C}$.
In the next stage, DNA was isolated from the samples using commercial kits for DNA isolation (following the manufacturers' protocols which included lysis of leukocytes and proteins in the samples), in order to select the optimal one: GeneMATRIX Quick Blood DNA Purification Kit (EURx); GeneJET (Fermentas); QIAamp DNA Blood (QIAGEN); Blood Mini (A\&A Biotechnology); and Genomic Mini (A\&A Biotechnology). DNA was eluted from the columns with the use of $100 \mu \mathrm{L}$ Tris buffer. In the case of each set, DNA was isolated from 16 samples.

\section{DNA Amplification}

All the processes of DNA amplification were performed with the use of the real-time PCR method (rtPCR) in a thermocycler CFX96 (BioRad) by employing species-specific primers and TaqMan probes. The sequences of oligonucleotides utilized in the research and amplification procedures are presented in Table 1.

Additionally, in every sample of DNA extract from blood, $\beta$-actin gene detection was performed in order to check whether rtPCR inhibition takes place; $\mathrm{SYBR}^{\circledR}$ Green JumpStart Taq ReadyMix (Sigma) was used for that purpose [9].

\section{DNA Purity and Concentration}

The concentration and purity of total DNA extract in the samples were measured spectrophotometrically at wavelengths of $A_{260}$ and $A_{280}$. Heme concentration in the samples was measured at wavelength of $A_{388}$ [4]. The measurement was performed in DNA extracts obtained from whole blood and subjected to preliminary processing. It was performed in a NanoDrop machine (Thermo Scientific).

The contents of microbial DNA in the samples were determined with the help of the rtPCR method using species-specific primers and TaqMan probes (Table 1). Amplification mixture in $10 \mu \mathrm{L}$ volume: $0.3 \mathrm{U}$ Perpetual Taq polymerase (EURx), $200 \mu \mathrm{M}$ dNTP (EURx), $7.75 \mathrm{mM}$ magnesium chloride (EURx), $200 \mathrm{nM}$ primer ( $\mathrm{F}$ and $\mathrm{R}$ ) (Genomed), $300 \mathrm{nM}$ probe (Genomed), and $3 \mu \mathrm{L}$ DNA. Amplification detection limit was defined as the relation of the $C_{\mathrm{T}}$ value, i.e., the number of reaction cycle in which the linear increase of the product cuts an established baseline at 30 RFU.

Evaluation of the rtPCR Method Detection Limit

The evaluation of the PCR method detection limit consisted in simultaneously inoculating the blood samples taken from healthy volunteers with four reference strains simultaneously (E. coli, S. aureus, C. albicans, and 
Table 1 Oligonucleotide sequences employed in DNA amplification reactions of the four microbes

\begin{tabular}{|c|c|c|}
\hline Microbe species & $5^{\prime}-3^{\prime}$ & Amplification procedure \\
\hline Gram (-) E. coli & $\begin{array}{l}\text { (F) GGGAGTAAAGTTAATACCTTTGC } \\
\text { (R) CTCAAGCTTGCCAGTATCAG } \\
\text { FAM-CGCGATCACTCCGTGCCAG } \\
\text { CAGCCGCGGATCGCG-BHQ1 [2] }\end{array}$ & $\begin{array}{l}95{ }^{\circ} \mathrm{C} \text { for } 2 \min \left(95^{\circ} \mathrm{C} \text { for } 15 \mathrm{~s}, 55^{\circ} \mathrm{C}\right. \\
\left.\text { for } 30 \mathrm{~s}, 72^{\circ} \mathrm{C} \text { for } 30 \mathrm{~s}\right) 50 \text { cycles }\end{array}$ \\
\hline Gram (+) S. aureus & $\begin{array}{l}\text { (F) TACATGTCGTTAAACCTGGTG } \\
\text { (R) TACAGTTGTACCGATGAATGG } \\
\text { (P) FAM-CGCGATCCAAGAACTTGTTGTTG } \\
\text { ATAAGAAGCAACCGATCGCG-BHQ1 [2] }\end{array}$ & $\begin{array}{l}95^{\circ} \mathrm{C} \text { for } 2 \min \left(95{ }^{\circ} \mathrm{C} \text { for } 15 \mathrm{~s}, 61^{\circ} \mathrm{C}\right. \\
\left.\text { for } 30 \mathrm{~s}, 72{ }^{\circ} \mathrm{C} \text { for } 30 \mathrm{~s}\right) 50 \text { cycles }\end{array}$ \\
\hline C. albicans yeast & $\begin{array}{l}\text { (F) TTGGTGGAGTGATTTGTCTGCT } \\
\text { (R) TCTAAGGGCATCACAGACCTG } \\
\text { (P) FAM-TTAACCTACTAAATAGTGCTGCT } \\
\text { AGC-BHQ1 [8] }\end{array}$ & $\begin{array}{l}95{ }^{\circ} \mathrm{C} \text { for } 2 \min \left(95^{\circ} \mathrm{C} \text { for } 15 \mathrm{~s}, 55^{\circ} \mathrm{C}\right. \\
\left.\text { for } 30 \mathrm{~s}, 72{ }^{\circ} \mathrm{C} \text { for } 30 \mathrm{~s}\right) 50 \text { cycles }\end{array}$ \\
\hline $\begin{array}{l}\text { A. fumigatus filamentous } \\
\text { fungus }\end{array}$ & $\begin{array}{l}\text { (F) TTGGTGGAGTGATTTGTCTGCT } \\
\text { (R) TCTAAGGGCATCACAGACCTG } \\
\text { (P) FAM-TCGGCCCTTAAATAGCCCGG } \\
\text { TCCGC-BHQ1 [8] }\end{array}$ & $\begin{array}{l}95{ }^{\circ} \mathrm{C} \text { for } 2 \min \left(95^{\circ} \mathrm{C} \text { for } 15 \mathrm{~s}, 61^{\circ} \mathrm{C}\right. \\
\left.\text { for } 30 \mathrm{~s}, 72^{\circ} \mathrm{C} \text { for } 30 \mathrm{~s}\right) 50 \text { cycles }\end{array}$ \\
\hline$\beta$-actin gene & $\begin{array}{l}\text { (F) GCCAGTGCCAGAAGAGCCAA } \\
\text { (R) TTAGGGTTGCCCATAACAGC [9] }\end{array}$ & $\begin{array}{l}95{ }^{\circ} \mathrm{C} \text { for } 5 \mathrm{~min}\left(95^{\circ} \mathrm{C} \text { for } 30 \mathrm{~s}, 55^{\circ} \mathrm{C}\right. \\
\left.\text { for } 30 \mathrm{~s}, 72^{\circ} \mathrm{Cfor} 1 \mathrm{~min}\right) 30 \text { cycles and } \\
\text { final extension at } 72^{\circ} \mathrm{C} \text { for } 5 \mathrm{~min}\end{array}$ \\
\hline
\end{tabular}

$F$ forward primer, $R$ reverse primer, $P$ probe

Table 2 Volumes of DNA and whole reaction solutions
The amplification procedure involved 50 cycles

\begin{tabular}{|c|c|c|c|c|}
\hline & \multicolumn{4}{|l|}{ Volume of } \\
\hline & $\begin{array}{l}\text { Blood sample } \\
\text { volume }(\mathrm{mL})\end{array}$ & $\begin{array}{l}\text { The final DNA } \\
\text { eluate }(\mu \mathrm{L})\end{array}$ & $\begin{array}{l}\text { Amplification } \\
\text { reaction }(\mu \mathrm{L})\end{array}$ & $\begin{array}{l}\text { Template } \\
\text { added }(\mu \mathrm{L})\end{array}$ \\
\hline $\begin{array}{l}\text { E. coli } \\
\text { S. aureus } \\
\text { C. albicans } \\
\text { A. fumigatus }\end{array}$ & 1 & 200 & 10 & 3 \\
\hline $\begin{array}{l}\text { E. coli } \\
\text { S. aureus } \\
\text { C. albicans } \\
\text { A. fumigatus }\end{array}$ & 1.5 & 300 & 60 & 30 \\
\hline $\begin{array}{l}\text { E. coli } \\
\text { S. aureus } \\
\text { C. albicans } \\
\text { A. fumigatus }\end{array}$ & 5 & 200 & 10 & 3 \\
\hline
\end{tabular}

A. fumigatus), in the same blood sample, so as to obtain a gradient of their number from $10^{5}$ to $10^{\circ} \mathrm{CFU} / \mathrm{mL}$ - the number of the A. fumigatus conidia was determined by counting in a Bürker chamber. Later, DNA was isolated with the use of the prepared methodology and the chosen kit for DNA isolation. The indication of detection limit was performed for three different blood volumes, i.e., 1, 1.5, and $5 \mathrm{~mL}$. DNA was eluted from the columns with the volumes of elution buffer presented in Table 2 .

Subsequently, an amplification reaction was conducted with species-specific primers and TaqMan probes
(Table 1). This was done individually for each microbe species, in each of their blood dilutions, with the Perpetual Taq polymerase (EURx). The procedure of amplification consisted of 50 cycles (Table 1). Amplification mixture: 0.3 U Perpetual Taq polymerase (EURx), $200 \mu \mathrm{M}$ dNTP (EURx), $7.75 \mathrm{mM}$ magnesium chloride (EURx), $200 \mathrm{nM}$ primer ( $\mathrm{F}$ and $\mathrm{R}$ ) (Genomed), and $300 \mathrm{nM}$ probe (Genomed). Volumes of DNA solutions (and whole reaction volumes) used are presented in Table 2. DNA isolation and PCR reactions were conducted in five repetitions. Amplification reaction detection limit was determined on the 
basis of the comparison of parameter $C_{\mathrm{T}}$ value, i.e., the consecutive reaction cycle number in which the linear increase of the product cut the established baseline at 30 RFU.

\section{Statistics}

In the statistical analysis, Levene's test was applied-in order to confirm the equality of variances-followed by an ANOVA test. Significant differences were established to be of statistical significance of $P<0.05$. All calculations were conducted using Gretl software ver. 1.9.4.

\section{Results}

Preliminary Processing of Blood Samples for Bacterial and Fungal DNA Isolation

As a result of a series of experiments, the following bloodprocessing procedure was formulated: $6 \mathrm{~mL}$ of $0.17 \mathrm{M}$ ammonium chloride (POCh) was added to $1.5 \mathrm{~mL}$ of whole blood and incubated at $37{ }^{\circ} \mathrm{C}$ for $20 \mathrm{~min}$. Then, the samples were centrifuged at the speed of $10,000 \mathrm{rpm}$ for $10 \mathrm{~min}$ and the supernatant was removed. The sediment was suspended in a $100 \mu \mathrm{L}$ solution of lysozyme $(2 \mathrm{mg} /$ $\mathrm{mL}$ ) (Sigma) and lysostaphin $(0.2 \mathrm{mg} / \mathrm{mL})$ (Sigma) in PBS buffer. The whole mixture was transferred to test tubes with glass beads $700-1,100 \mu \mathrm{m}$ (Sigma) and subjected to mechanical disintegration in FastPrep (MP Biomedicals) machine for $20 \mathrm{~s}$, at speed $4.0 \mathrm{~m} / \mathrm{s}$ - the mixture was all incubated for $30 \mathrm{~min}$ at $37{ }^{\circ} \mathrm{C} .200 \mu \mathrm{L} 75 \mathrm{mM} \mathrm{NaOH}$ (POCh) was added to the samples and incubated for $10 \mathrm{~min}$ at $95{ }^{\circ} \mathrm{C}$. Next, it was centrifuged at speed $12,000 \mathrm{rpm}$ for $10 \mathrm{~min}$ and the supernatant was discarded. $500 \mu \mathrm{L}$ of buffer consisting of $50 \mathrm{mM}$ Tris- $\mathrm{HCl} \mathrm{pH} 7.5$ (Sigma), $10 \mathrm{mM}$ EDTA (Sigma), $28 \mathrm{mM} \quad \beta$-mercaptoethanol (Sigma), and lyticase $40 \mathrm{U}$ (Sigma) was added to the sediment. The samples were incubated for $30 \mathrm{~min}$ at $37{ }^{\circ} \mathrm{C}$ and then centrifuged at $12,000 \mathrm{rpm}$ for $10 \mathrm{~min}$. The obtained pellet was submitted to further processing with the use of commercial kits for DNA isolation.

Evaluation of the Available Commerical Kits for DNA Isolation

DNA was isolated from blood samples subjected to the processing described above with the use of five commercial kits according to the protocols provided by the manufacturers: GeneMATRIX Quick Blood DNA Purification Kit (EURx); GeneJET (Fermentas); QIAamp DNA Blood (QIAGEN); Blood Mini (A\&A Biotechnology); and Genomic Mini (A\&A Biotechnology).

In the DNA extract obtained, the measurement of the total concentration of DNA and its purity was performed. The highest concentration of deoxyribonucleic acid was found in the isolates obtained with Genomic Mini (A\&A Biotechnology) kit-31.99 ng/mL (Fig. 1). The highest purity was noted in DNA extract from the Blood Mini (A\&A Biotechnology) set-1.95 ng/mL (Fig. 1). No significant differences were demonstrated between the kits as regards the measured purity and concentration of DNA.
Fig. 1 Comparison of kits for isolating DNA from blood as regards the obtained degree of total DNA concentration and its purity, with the application of the developed preliminary blood sample methodology

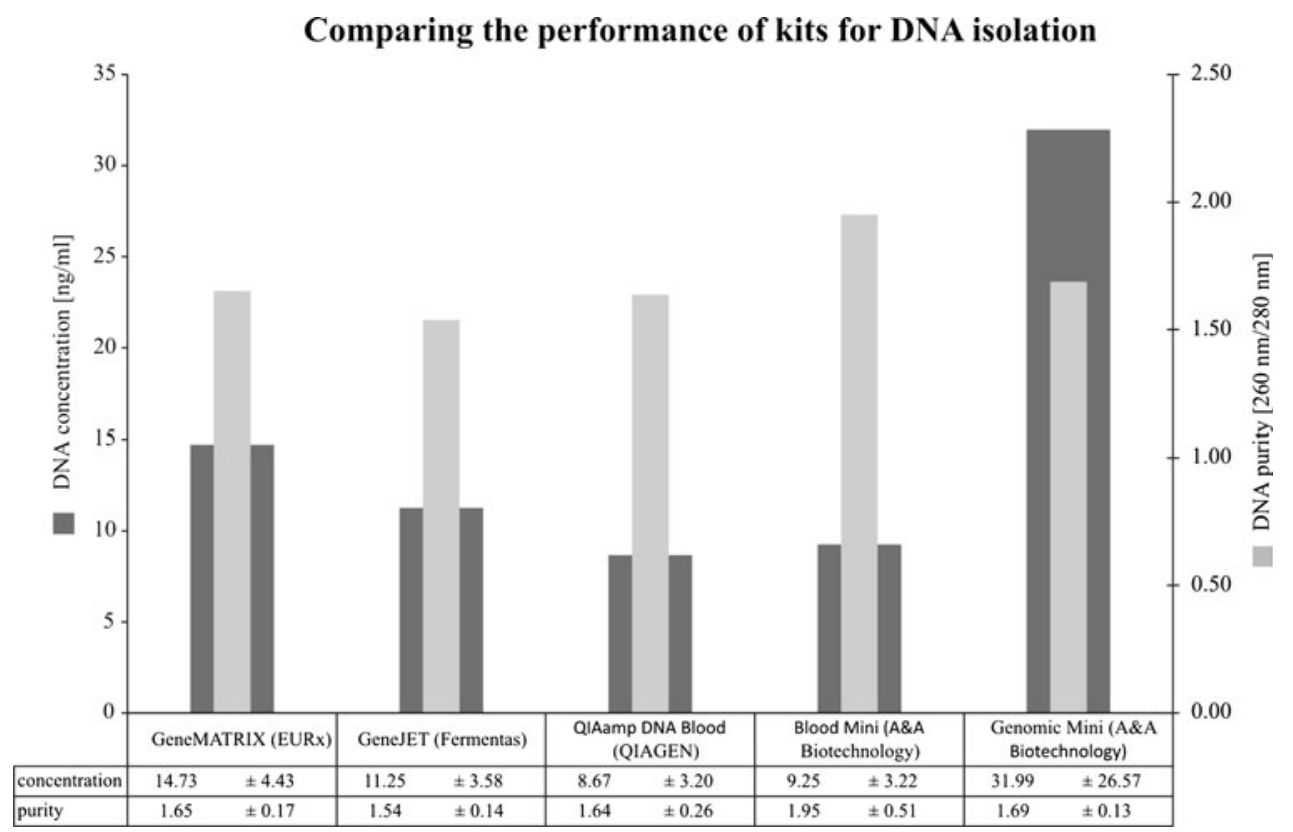


a

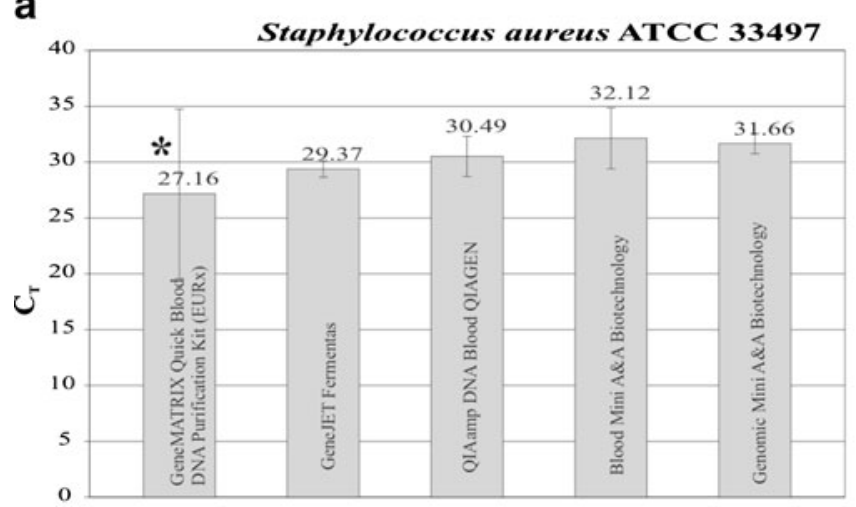

C

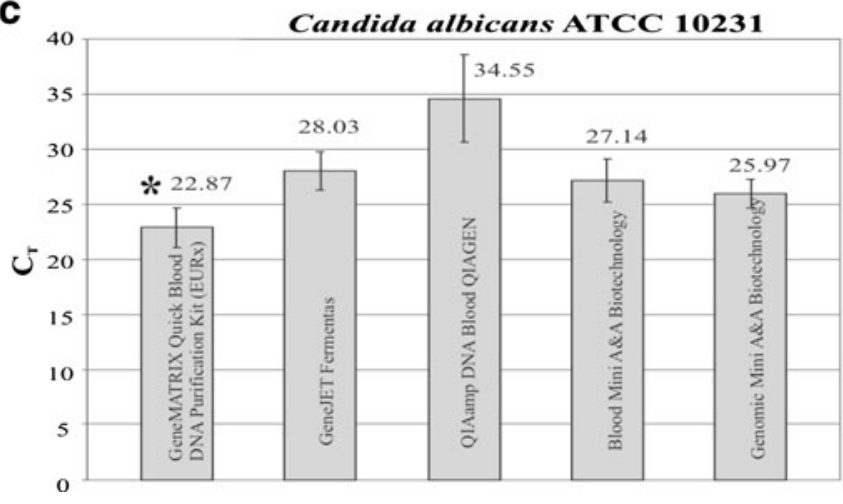

Fig. 2 Comparison of DNA content of the microbes: a $S$. aureus, b E. coli, $\mathbf{c}$ C. albicans, and $\mathbf{d}$ A. fumigatus in DNA samples isolated from blood with the application of the elaborated preliminary

An evaluation of DNA concentration of the four representatives of the studied microbial species was also performed in the isolated samples. In the case of each set, amplification signal was registered quickly in the DNA samples isolated from blood subjected to preliminary processing. Additionally, GeneMATRIX Quick Blood DNA Purification Kit (EURx) proved to be the best, as the following results were recorded here: $S$. aureus $\left(C_{\mathrm{T}}=27.16\right)$, E. coli $\left(C_{\mathrm{T}}=21.11\right), C$. albicans $\left(C_{\mathrm{T}}=22.87\right)$, and $A$. fumigatus $\left(C_{\mathrm{T}}=24.09\right)$ (Fig. 2a-d). The aforementioned values were significantly different $(P<0.001)$ from the ones obtained with the use of the remaining kits as regards each species. It is an indication that the use of preliminary processing together with the GeneMATRIX Quick Blood DNA Purification Kit (EURx) permits DNA amplification signal to be received faster than from the remaining kits under study.

A measurement of heme concentration was also performed in the samples obtained from each of the studied kits for DNA isolation, upon the use of preliminary processing of blood samples or without it. The preliminary procedure allowed the removal of substantially greater

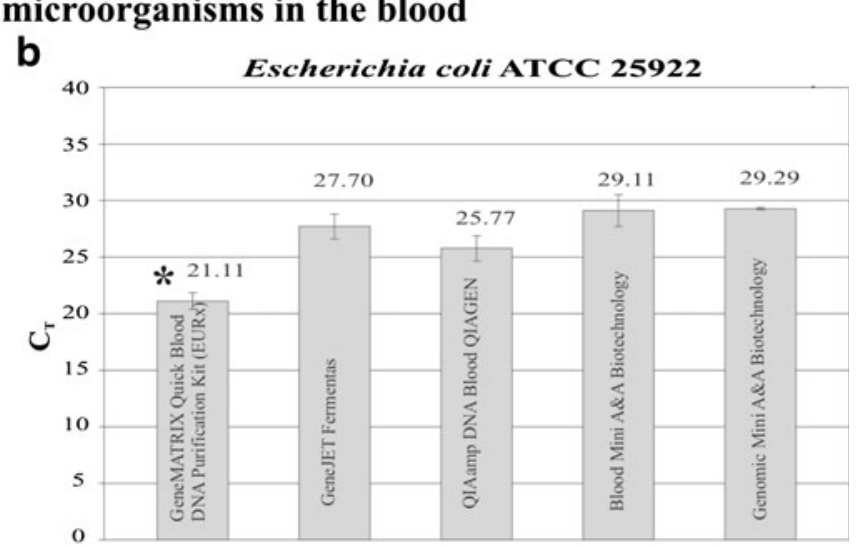

d

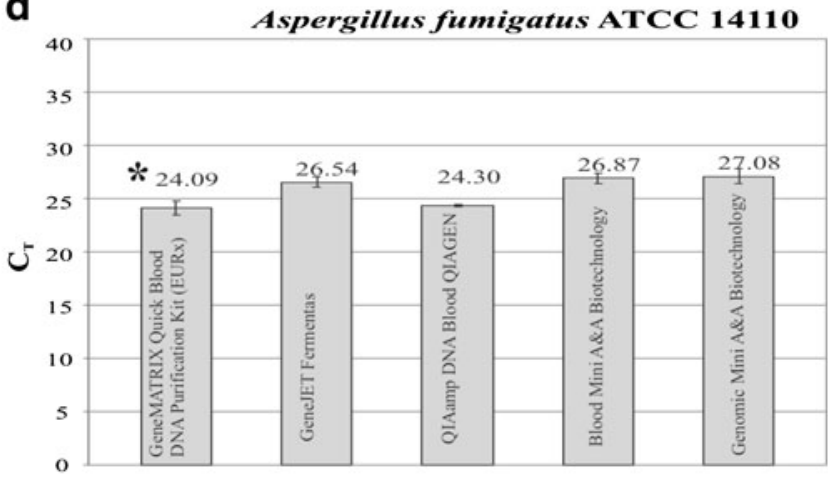

processing method for blood samples and the studied DNA isolation kits. Asterisk values significantly different from the remaining ones for a given microbe $(P<0.001)$

$(P<0.05)$ amount of heme than without its application in all of the kits with the exception of QIAamp DNA Blood (QIAGEN), where no significant difference was shown (Fig. 3). The most effective sets as regards removing heme from samples submitted to preliminary processing were: GeneMATRIX Quick Blood DNA Purification Kit (EURx) - 2.76 $\mu \mathrm{M}$ and Blood Mini (A\&A Biotechnology) $-2.73 \mu \mathrm{M}$, where the obtained results were significantly $(P<0.05)$ different from the remaining ones, while no significant differences between those kits were shown (Fig. 3). The method omitting preliminary processing did not allow obtaining significant differences between the studied commercial sets. The heme concentration in the blood samples isolated directly with the use of commercial kits yielded from 4.48 to $8.18 \mu \mathrm{M}$ (Fig. 3).

Detection Limit of the Studied Microbes with the Use of the rtPCR Method

The minimal limit number of studied microorganisms, the presence of which could be detected in blood during the performed rtPCR reaction, was defined as the method 
Fig. 3 Comparison of the degree of heme concentration in DNA extract obtained with the use of DNA isolation kits both when the developed preliminary blood sample processing was applied and without it. Asterisk the significantly different results of heme concentration comparison within one DNA isolation kit when applying preliminary blood samples processing and without it; Hash results received by applying preliminary blood samples processing significantly different from the remaining kits under study $(P<0.05)$

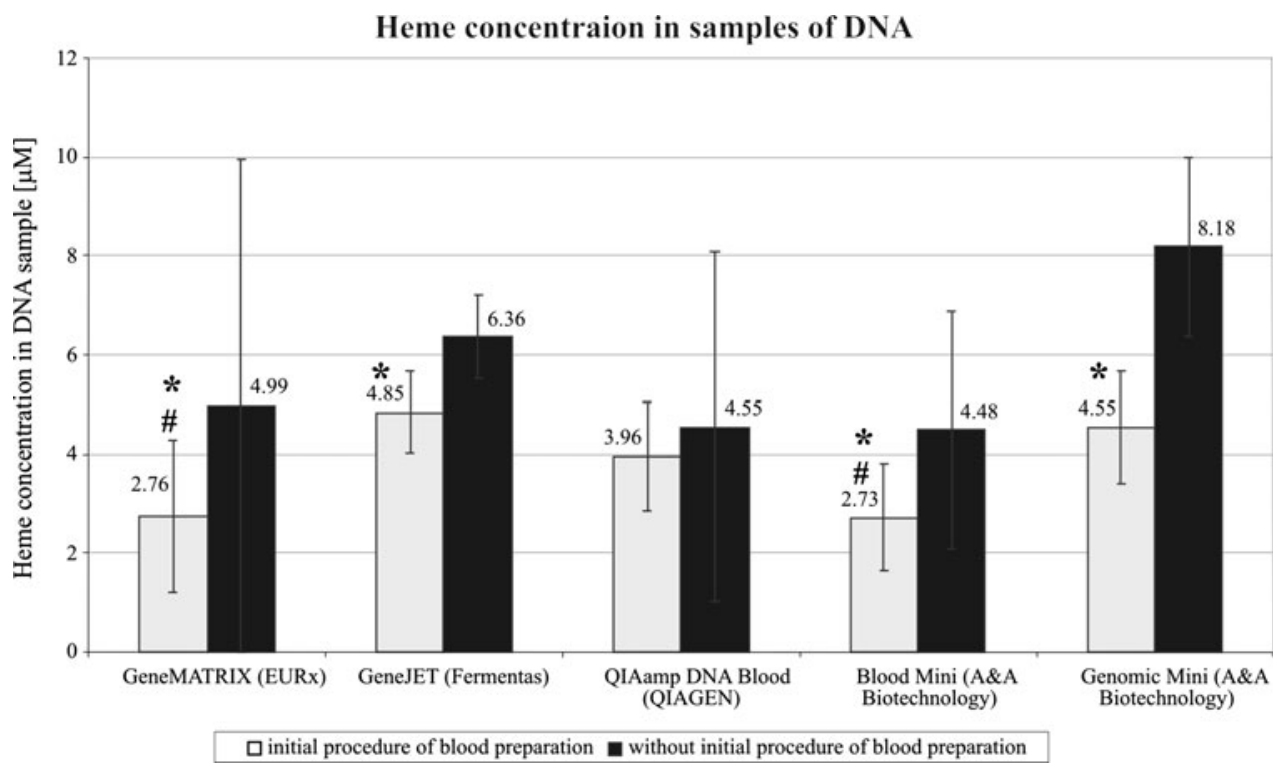

detection limit. A positive result of the amplification reaction indicated that the fluorescence intensity of the PCR product was higher than the one determined for the baseline, at $30 \mathrm{RFU}$. As regards the DNA samples isolated from 1 to $5 \mathrm{~mL}$ of blood, the boundary detection signal for microbial DNA remained at the same level: $E$ coli$3.0 \times 10^{1} \mathrm{CFU} / \mathrm{mL}, \quad$ S. aureus-3.0 $\times 10^{3} \mathrm{CFU} / \mathrm{mL}$, C. albicans-3.0 $\times 10^{4} \mathrm{CFU} / \mathrm{mL}$, and A. fumigatus $3.0 \times 10^{3} \mathrm{CFU} / \mathrm{mL}$. Isolation from $1.5 \mathrm{~mL}$ of blood and the increased volume of elution and DNA content in the reaction mixture allowed raising the determination detection limit per one order of magnitude for A. fumigatus $\left(3.0 \times 10^{2} \mathrm{CFU} / \mathrm{mL}\right)$ and E. coli $\left(3.0 \times 10^{\circ} \mathrm{CFU} / \mathrm{mL}\right)$ and two orders of magnitude for $S$. aureus $\left(3.0 \times 10^{1} \mathrm{CFU} /\right.$ $\mathrm{mL})$ and $C$. albicans $\left(3.0 \times 10^{2} \mathrm{CFU} / \mathrm{mL}\right)$. The determination was conducted five times and the result was considered significant if the detection signal was received in at least three repetitions.

\section{Discussion}

Detection of microorganisms in blood with the use of the PCR method requires prior isolation of their DNA. Isolation of DNA from leukocytes does not present difficulties as white blood cells are surrounded only by a thin cell membrane. The microbial cell structure brings about the necessity to apply additional processes which could allow digesting their cell walls (e.g., enzymatic lysis) in order to gain access to nucleic acids. The matters get complicated even further because of the fact that blood may contain microorganisms of various cell wall structures, i.e., not only Gram-positive and Gram-negative bacteria, but also yeast or filamentous fungi. Consequently, it is necessary to compile several processes, enabling obtaining high-quality DNA matrix, in order to develop an efficient method for microbial DNA isolation from blood.

In scientific literature, methods for bacterial and fungal DNA isolation from blood are described, but they are enabling one to separately isolate either bacterial or fungal DNA from blood [1, 2, 6, 8, 12].

Also ready-to-use brand name kits for isolating DNA from blood are designed to obtain deoxyribonucleic acid from either only blood or, upon the introduction of an additional stage, from bacteria or from fungi, e.g., QIAamp DNA Blood (QIAGEN) or Blood Mini (A\&A Biotechnology). On the market, there are several ready-to-use kits for microbial, both bacterial and fungal, DNA detection from blood, such as Septifast (Roche) or Septitest (Molzym), which enable complex DNA isolation. Yet, there still exists a need for devising new methods of efficient diagnostics of molecular sepsis.

In the present study, a method has been suggested which enables simultaneous DNA isolation of a Gram-negative bacterium E. coli ATCC 25922, a Gram-positive one $S$. aureus ATCC 33497, C. albicans ATCC 10231 yeast, and a filamentous fungus A. fumigatus ATCC 14110 from blood. The four species represent groups of microorganisms which are varied as regards their cell wall structure and can cause sepsis. The developed procedure consisted of three consecutive steps, i.e., mechanical disruption, chemical lysis, and thermal lysis. Afterward, DNA was isolated from the previously prepared samples with the use of several commercial kits for DNA isolation. As was demonstrated in this study, such a procedure allowed obtaining DNA from all four microorganisms under study in the amount sufficient to conduct the rtPCR reaction, which aimed at detecting them in blood. As shown, the 
lowest sensitivity demonstrated for A. fumigatus cells what is associated with composition of its cell wall which is thicker than bacterial cell wall. The GeneMatrix Quick Blood DNA Purification Kit (EURx) proved to be significantly better than the others (Fig. 2a-d). Other authors conducted comparative studies for microbial DNA isolation kits, but they concerned either only bacteria in blood or fungi suspended in an appropriate buffer $[6,7]$. The results obtained by them concerned different volumes of blood samples and various isolation kits; moreover, no preliminary processing procedure was applied, so there is no possibility of comparing the results with ours.

The elaborated methodology was also evaluated in terms of the detection limit of E. coli, S. aureus, C. albicans, and A. fumigatus depending on the volume of blood samples utilized for DNA isolation. The analysis of the received results permitted to conclude that there is no difference in the detection limit of the method in the case of DNA isolation in 1 and $5 \mathrm{~mL}$ volumes; however, the detection limit for E. coli, S. aureus, C. albicans, and A. fumigates could be increased by isolating DNA from $1.5 \mathrm{~mL}$ of blood and utilizing DNA matrix in the process of amplification in the volume of $30 \mu \mathrm{L}$ by the mixture volume of $60 \mu \mathrm{L}$. This effect is presumably a result of the use of a much larger DNA volume for amplification, which increased the probability of a sequence of microorganism species to appear in a sample in the event of their limit number. The determined method detection limit for detection of the four species allowed to distinguish the number of microbial cells in blood in the quantity of: $3 \mathrm{CFU} / \mathrm{mL}$ for $E$. coli and $30 \mathrm{CFU} /$ $\mathrm{mL}$ for $S$. aureus, whereas the yeast and the filamentous fungus were characterized by the level of $300 \mathrm{CFU} / \mathrm{mL}$. The obtained results differ from the ones received with the use of SeptiFast (Roche) kit, where they amounted to $3 \mathrm{CFU} / \mathrm{mL}$ for $E$. coli, $30 \mathrm{CFU} / \mathrm{mL}$ for $S$. aureus, $30 \mathrm{CFU} / \mathrm{mL}$ for $C$. albicans, and $3 \mathrm{CFU} / \mathrm{mL}$ for A. fumigatus [11]. In the case of the fungi, the detection limit determined in this paper is lower, which can be explained by the fact that the methodology presented here assumed the use of $30 \mu \mathrm{L}$ of DNA as matrix for amplification; while in the case of SeptiFast (Roche) kit, $50 \mu \mathrm{L}$ was used. The detection limit of detection for both species of bacteria was identical, which probably is connected to the fact that their cell wall gives into lysis much more easily; therefore, it is possible to get more DNA from the same number of cells in comparison to fungi.

Molecular diagnostic of sepsis is a very hard task. It is still the case that blood culture remains the basic diagnostic method, although theoretically there exists technical potential to detect microbes with the use of molecular methods. The difficulties described in this study delimit the direction of essential research, which has to be carried out in order to draw up an efficient and complex method for microbial DNA isolation from the blood.
Acknowledgments This study was supported by Polish Ministry of Science and Higher Education within the frame work of project Grant No. N401 006739. The second author Leszek Szała was supported by RVO funding for IČ47813059.

Open Access This article is distributed under the terms of the Creative Commons Attribution License which permits any use, distribution, and reproduction in any medium, provided the original author(s) and the source are credited.

\section{References}

1. Badiee P, Alborzi A (2010) Detection of Aspergillus species in bone marrow transplant patients. J Infect Dev Ctries 4:511-516

2. Chiba N, Murayama SY, Morozumi M, Nakayama E, Okada T, Iwata S, Sunakawa K, Ubukata K (2009) Rapid detection of eight causative pathogens for the diagnosis of bacterial meningitis by real-time PCR. J Infect Chemother 15:92-98

3. Jamal W, Tamaray G, Pazhoor A, Rotimi VO (2006) Comparative evaluation of BacT/ALERT 3D and BACTEC systems for the recovery of pathogens causing bloodstream infections. Med Princ Pract 15:223-227

4. Lombardo ME, Araujo LS, Ciccarelli AB, Batlle A (2005) A spectrophotometric method for estimating hemin in biological systems. Anal Biochem 341:199-203

5. Mauro MV, Cavalcanti P, Perugini D, Noto A, Sperli D, Giraldi C (2012) Diagnostic utility of LightCycler SeptiFast and procalcitonin assays in the diagnosis of bloodstream infection in immunocompromised patients. Diagn Microbiol Infect Dis 73:308-311

6. Nawrot U, Wlodarczyk K, Wrobel M, Wasik A, Dobosz T (2010) Comparison of the utility of five commercial kits for extraction of DNA from Aspergillus fumigatus spores. Acta Biochim Pol 57:567-571

7. Smith K, Diggle MA, Clarke SC (2003) Comparison of commercial DNA extraction kits for extraction of bacterial genomic DNA from whole-blood samples. J Clin Microbiol 41:2440-2443

8. Sugita S, Kamoi K, Ogawa M, Watanabe K, Shimizu N, Mochizuki M (2012) Detection of Candida and Aspergillus species DNA using broad-range real-time PCR for fungal endophthalmitis. Graefes Arch Clin Exp Ophthalmol 250:391-398

9. Valle DL Jr, Andrade JI, Cabrera EC, Rivera WL (2010) Evaluation of buffy coat $16 \mathrm{~S}$ rRNA PCR, buffy coat culture and whole blood PCR for detection of bacteraemia. Mem Inst Oswaldo Cruz 105:117-122

10. Wellinghausen N, Kochem AJ, Disque C, Mühl H, Gebert S, Winter J, Matten J, Sakka SG (2009) Diagnosis of bacteremia in whole-blood samples by use of a commercial universal $16 \mathrm{~S}$ rRNA gene-based PCR and sequence analysis. J Clin Microbiol 47:2759-2765

11. Westh H, Lisby G, Breysse F, Böddinghaus B, Chomarat M, Gant V, Goglio A, Raglio A, Schuster H, Stuber F, Wissing H, Hoeft A (2009) Multiplex real-time PCR and blood culture for identification of bloodstream pathogens in patients with suspected sepsis. Clin Microbiol Infect 15:544-551

12. Yang S, Ramachandran P, Hardick A, Hsieh YH, Quianzon C, Kuroki M, Hardick J, Kecojevic A, Abeygunawardena A, Zenilman J, Melendez J, Doshi V, Gaydos C, Rothman RE (2008) Rapid PCR-based diagnosis of septic arthritis by early gram-type classification and pathogen identification. J Clin Microbiol 46:1386-1390 